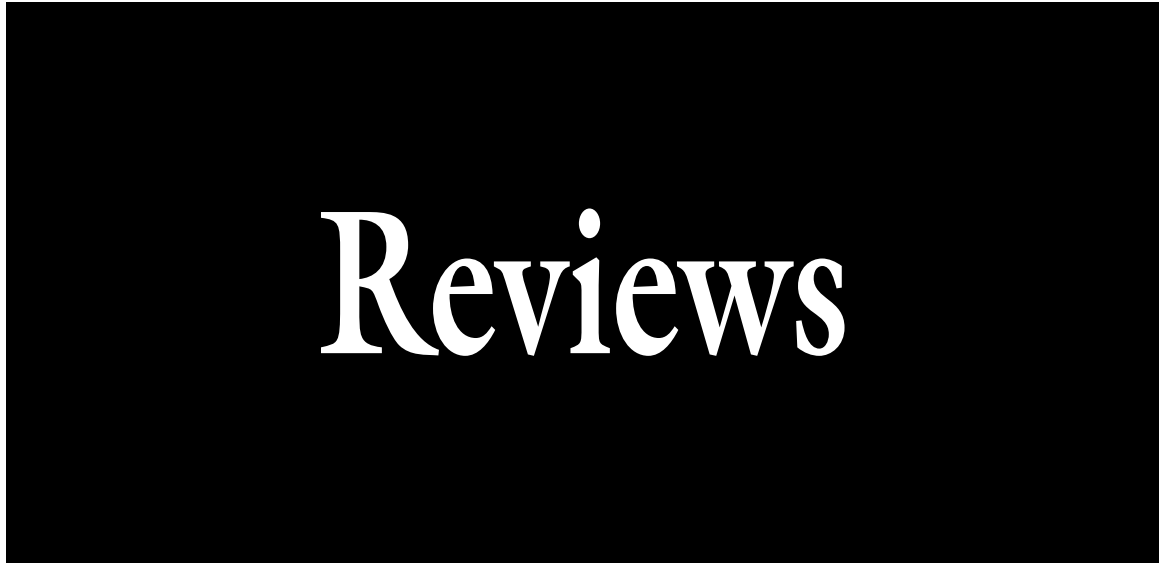

\title{
Subirrigation: Historical Overview, Challenges, and Future Prospects
}

\author{
Rhuanito Soranz Ferrarezi ${ }^{1,4}$, Geoffrey Matthew Weaver ${ }^{2}$, \\ Marc W. van Iersel $^{2}$, and Roberto Testezlaf ${ }^{3}$
}

AdDITIONAL INDEX wORDs. irrigation, ebb-and-flow, flood-floor, greenhouse, nursery, water-saving technologies

SUMMARY. Subirrigation is a greenhouse irrigation method that relies on capillary action to provide plants with water and nutrients from below their containers. The first documented subirrigation system was described in $\mathbf{1 8 9 5}$, and several variations on the basic design were used for research purposes before the modern ebb-and-flow type systems emerged in 1974. Most subirrigation systems apply the fertilizer solution to a waterproof bench or greenhouse section, allowing the substrate to absorb the water through holes in the bottom of the containers. Because there is little or no leaching, subirrigation typically allows for the use of lower fertilizer solution concentrations. Although excess fertilizer salts typically accumulate in the top layer of the substrate, this does not seem to have a negative impact on plants. Subirrigation can conserve nutrients and water, reduce labor costs, and help growers meet environmental regulations. A challenge with subirrigation is the potential spread of pathogens via the fertilizer solution. When this is a concern, effective disinfection methods such as ultraviolet radiation, chlorine, or ozone should be used. Sensor-based irrigation control has recently been applied to subirrigation to further improve nutrient and water use efficiencies. Better control of irrigation may help reduce the spread of pathogens, while at the same time improving crop quality. The primary economic benefit of subirrigation is the reduction in labor costs, which is the greatest expenditure for many growers.

G reenhouse production is a vital part of the horticulture industry, with nearly 20,000 acres devoted to commercial greenhouse production in the United States alone [U.S. Department of Agriculture (USDA), 2009]. Frequent fertilization and irrigation is necessary, because plants typically grow in a small volume of substrate from which nutrients and water are rapidly depleted. Common greenhouse practices include overhead and drip irrigation, and plants are typically watered according to a set schedule. When more water is applied than can be absorbed by the substrate, excess water and nutrients leach. This leachate can be collected and reused, but often runs off to the external environment. Nutrients lost through runoff can contribute to nitrate and phosphate contamination of ground and surface water. Government regulations gradually require greenhouse growers to minimize their environmental impact by limiting nutrient runoff. Increasing fertilizer costs provide further incentive for growers to conserve nutrients and prevent losses (Lea-Cox and Ross, 2001; Majsztrik et al., 2011).

Subirrigation is an irrigation technique that provides water or fertilizer solution to the bottom of containers. Capillary action of the substrate provides roots with water and nutrients. Greenhouse sections or benches with container-grown plants are periodically flooded within a closed system. The water or fertilizer solution is absorbed by the substrate through holes in the bottom of the container. The amount of water absorbed depends on substrate dryness, and irrigation volume closely matches plant requirements. Excess fertilizer solution is collected and reused for subsequent irrigation events, eliminating the environmental consequences associated with discharge, as well as reducing fertilizer costs for the producer (Bauerle, 1990; Bumgarner et al., 2008; Kang et al., 2004; Kang and van Iersel, 2004; Majsztrik et al., 2011; Zheng et al., 2004). Subirrigation also reduces the cost of labor, which is the largest expenditure for horticultural producers (USDA, 2009; Uva et al., 2001).

\section{History}

Subirrigation has been used since at least 1895 , when it was described by researchers at the Ohio Experimental Station (Green and Green, 1895). The subsequent development of hydroponics during the 1920s (Gericke, 1921, 1922) and sand-culture techniques in the 1930s (Biekart and Connors, 1935; Eaton, 1931) helped establish

\begin{tabular}{llll}
\hline $\begin{array}{l}\text { Units } \\
\text { To convert U.S. to SI, } \\
\text { multiply by }\end{array}$ & U.S. unit & SI unit & $\begin{array}{l}\text { To convert SI to U.S., } \\
\text { multiply by }\end{array}$ \\
\hline $\mathrm{l}$ & $\mathrm{cbar}$ & $\mathrm{kPa}$ & $\mathrm{l}$ \\
0.3048 & $\mathrm{ft}$ & $\mathrm{m}$ & 3.2808 \\
0.0929 & $\mathrm{ft}^{2}$ & $\mathrm{~m}^{2}$ & 10.7639 \\
0.0283 & $\mathrm{ft}^{3}$ & $\mathrm{~m}^{3}$ & 35.3147 \\
3.7854 & $\mathrm{gal}$ & $\mathrm{L}$ & 0.2642 \\
4.0746 & $\mathrm{gal} / 1000 \mathrm{ft}^{2}$ & $\mathrm{~L} / 100 \mathrm{~m}^{2}$ & 0.2454 \\
2.54 & inch $(\mathrm{es})$ & $\mathrm{cm}$ & 0.3937 \\
25.4 & inch $(\mathrm{es})$ & $\mathrm{mm}$ & 0.0394 \\
0.0254 & $\mathrm{mil}$ & $\mathrm{mm}$ & 39.3701 \\
1 & $\mathrm{mmho} / \mathrm{cm}$ & $\mathrm{dS} \cdot \mathrm{m}^{-1}$ & 1 \\
7.4892 & $\mathrm{oz} / \mathrm{gal}$ & $\mathrm{g} \cdot \mathrm{L}^{-1}$ & 0.1335 \\
1 & $\mathrm{ppm}$ & $\mathrm{mg} \cdot \mathrm{L}^{-1}$ & 1 \\
\end{tabular}


the principles underlying modern subirrigation systems. Independently conceived subirrigation systems were also in use at the New Jersey and Purdue University agricultural experiment stations during the 1930s (Withrow and Biebel, 1937).

An early sand-culture system used two separate tanks to supply irrigation water and collected runoff from a sand bed (Fig. 1). Excess water was eventually returned to the supply tank and electrical conductivity (EC) measurements were used to monitor nutrient concentrations of the recirculated solution (Eaton, 1931). A later, more refined system provided uniform nutrient supply, increased aeration, and further minimized waste. In this nutrient-culture system, sealed benches containing an inert medium were periodically flooded with fertilizer solution, which was collected for reuse in the same reservoir used to flood the benches (Withrow and Biebel, 1936) (Fig. 2). Timers were eventually added to reduce labor costs (Eaton, 1936; Gericke, 1937; Withrow and Biebel, 1937) (Fig. 3). Other adaptations of these basic designs were developed and used for research and commercial production through the 1930s and 1940s (Chapman and Liebig, 1938; Eaton, 1941; Thomas et al., 1943). In all of these systems, plants grew directly in irrigated sand or other substrate, rather than in containers.

Subirrigation with containerized plants was first described in 1950 as an improved and simplified alternative to the sand-culture and nutrient-culture techniques (Johnstone, 1950). In these systems, relatively small sand beds in one compartment were subirrigated

We thank FEAGRI/UNICAMP's Group of Irrigation Technology and Environment for the technical support and CAPES Foundation (Ministry of Education, Brazil) for a scholarship to the first author as research scholar at the University of Georgia (award no. BEX 1390/10-4). Funding for subirrigation research at UGA was provided by the American Floral Endowment and USDA-NIFASCRI (award no. 2009-51181-05768), while at UNICAMP by the National Council of Technological and Scientific Development (Ministry of Science and Technology, Brazil) (awards no. 479.394/2006-7 and 479.665/2009-5) and the State of São Paulo Research Foundation (FAPESP) (award no. 2012/01734-5).

${ }^{1}$ Agricultural Experimental Station, University of the Virgin Islands, RR\#1 Box 10,000, Kingshill, VI 00850

${ }^{2}$ Department of Horticulture, University of Georgia, 1111 Miller Plant Science Building, Athens, GA 30602

${ }^{3}$ School of Agricultural Engineering, University of Campinas, 501 Candido Rondon Street, Campinas, SP 13083-875, Brazil

${ }^{4}$ Corresponding author. E-mail: rhuanito.ferrarezi@ uvi.edu.

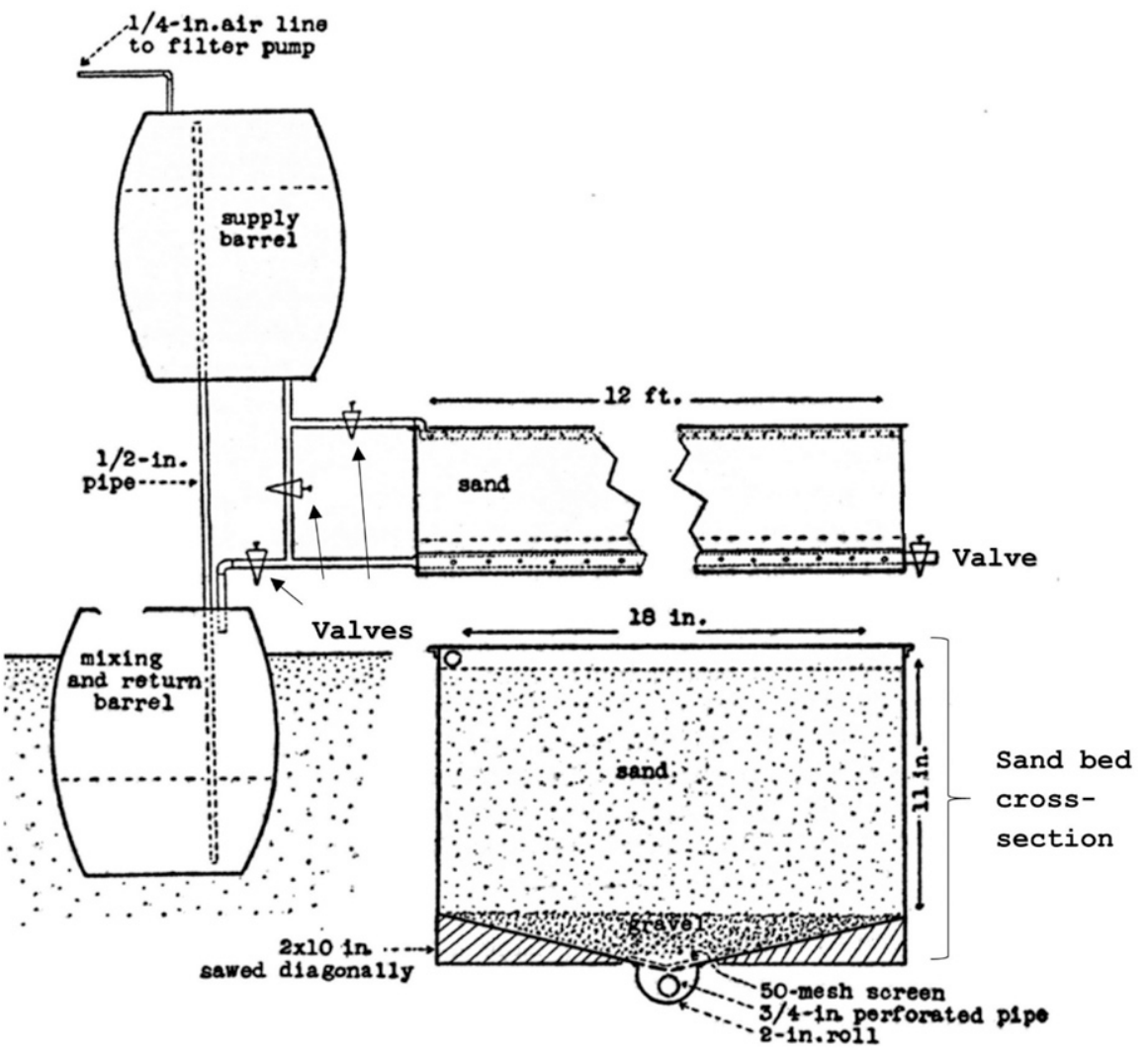

Fig. 1. Section of sand-culture apparatus showing the sand bed, solution barrels, and plumbing; 1 inch $($ in. $)=2.54 \mathrm{~cm}, 1 \mathrm{ft}(\mathrm{ft}$. $)=0.3048 \mathrm{~m}$, and 50 mesh $=0.297$ $\mathrm{mm}$ (0.0117 inch). Republished from Eaton (1931) with permission of Wolters Kluwer Health Inc.; permission conveyed through Copyright Clearance Center Inc.

with fertilizer solution from a lower reservoir. This system was used to commercially produce african violet (Saintpaulia ionantha) and impatiens (Impatiens walleriana), and was later redesigned to accommodate larger plants for experimental purposes (Johnstone, 1952) (Fig. 4). Unlike modern subirrigation systems, sand was used as the growing medium and fertilizer solution had to be discharged periodically due to changes in nutrient concentration (Johnstone, 1950, 1952).

Twenty-two years later, a fully automated, highly versatile subirrigation system was developed. Individual containerized plants, grown in soilless substrate, were housed in an upper reservoir and subirrigated with fertilizer solution from a lower reservoir using a submersible pump activated by a timer. Unabsorbed fertilizer solution returned to the lower reservoir through a slow drain and could be reused indefinitely. The system drained more slowly than it was filled, thereby allowing sufficient time for uptake of fertilizer solution by capillary action, and maintaining substrate water content near container capacity throughout the growing period. This system could be easily modified for use with various container and reservoir sizes and configured so that one reservoir could supply multiple benches (Stanwood et al., 1974) (Fig. 5). Similar designs, now known as ebb-and-flow systems, subsequently became popular (Bauerle, 1990; Biernbaum, 1988, 1990; Elliott, $1990,1992)$ and are the most common type of subirrigation used in the greenhouse industry (Uva et al., 1998) (Fig. 6).

\section{Equipment}

Subirrigation systems are classified as ebb-and-flow benches, flood-floor, trough-tray, wick system, mobile or Dutch trays, and capillary mat (Elia et al., 2003; Roeber, 2010). A study evaluating subirrigation use in $\mathbf{5 0}$ greenhouse establishments in 26 states indicated that ebb-and-flow is used by $58 \%$ of the growers, flood-floor by $13 \%$, and trough-tray systems by $8 \%$, with $21 \%$ of the interviewees having two or more systems (Uva et al., 1998). 


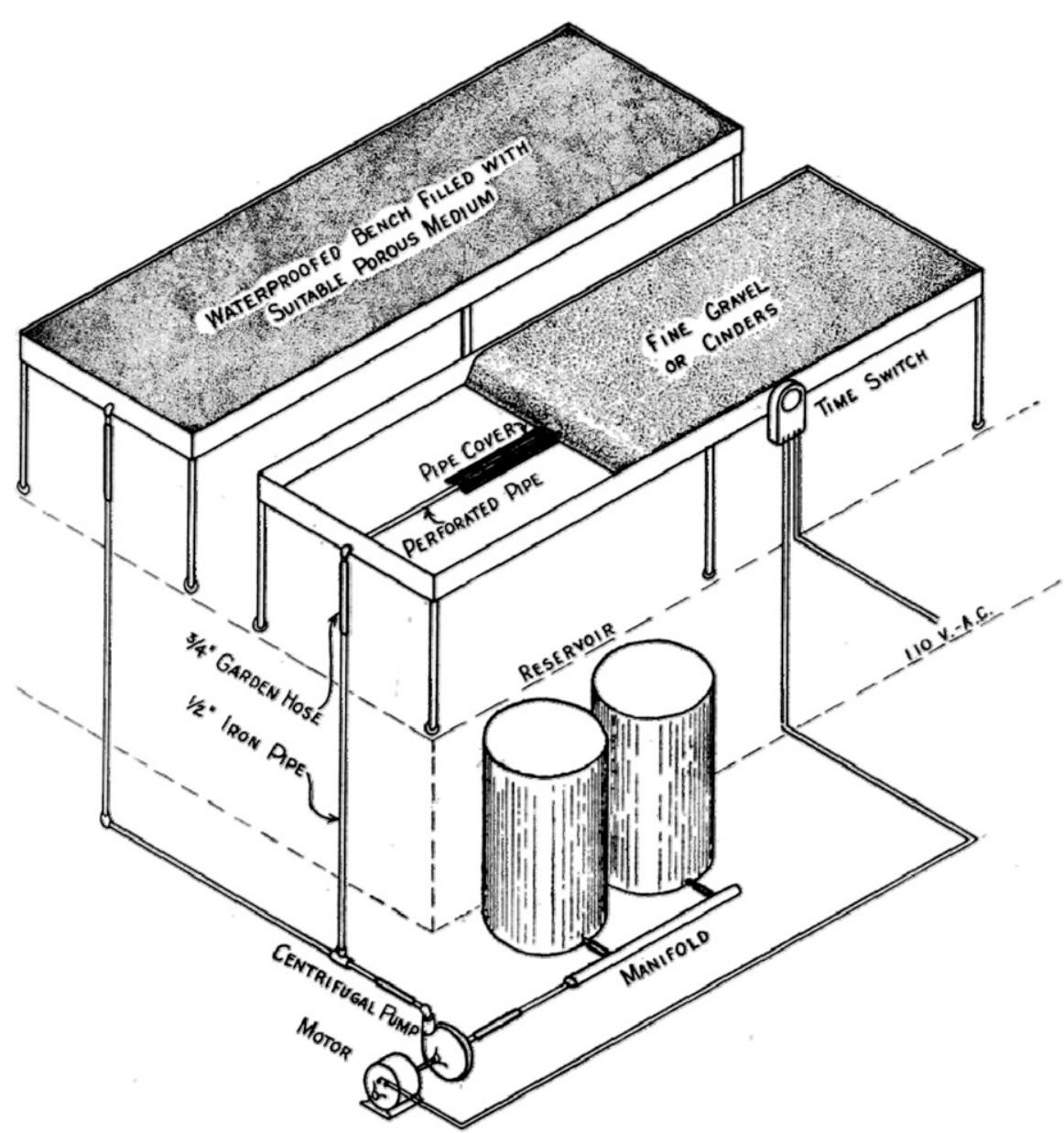

Fig. 2. Diagrammatic view of the subirrigation system for large-scale operation using two different substrates (porous media and fine gravel or cinders) (Withrow and Biebel, 1936); A.C. = alternating current, 1 inch $=2.54 \mathrm{~cm}$.

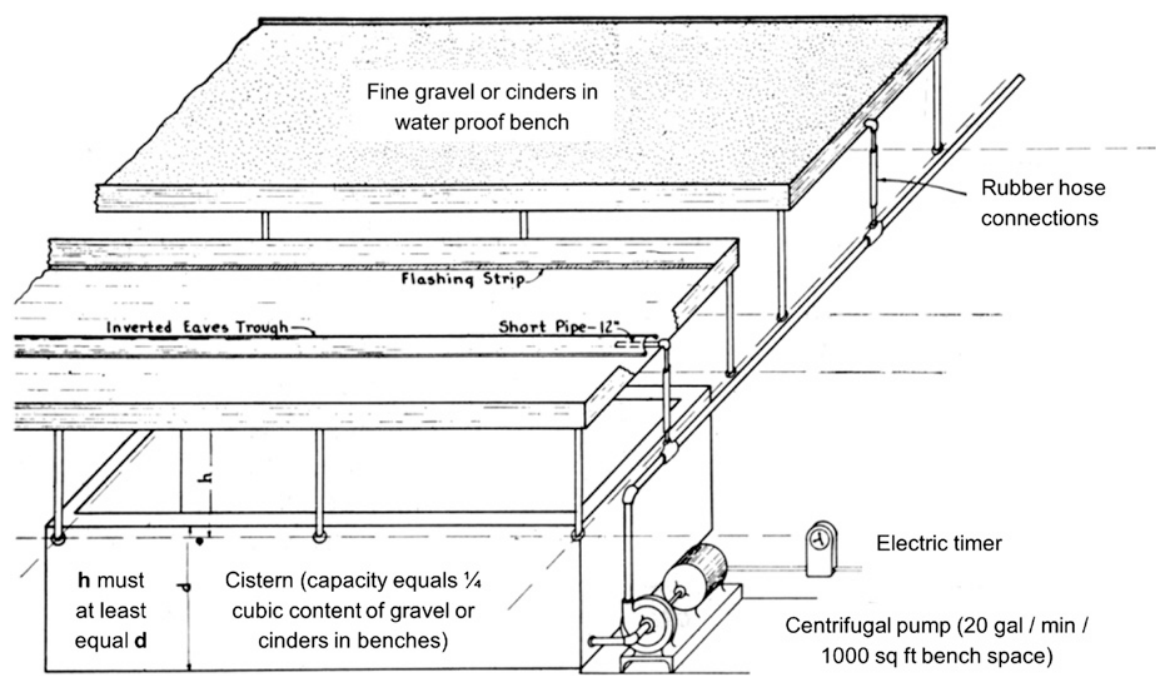

Fig. 3. Diagrammatic view of the subirrigation method of fertilizer solution culture. At that time, all pipes were made by black iron (no galvanized) (Withrow and Biebel, 1937); h = height, $\mathrm{d}=$ depth, 1 inch $=2.54 \mathrm{~cm}, 1 \mathrm{ft}^{2}(\mathrm{sq} \mathrm{ft})=0.0929 \mathrm{~m}^{2}, 1 \mathrm{gal} / 1000$ $\mathrm{ft}^{2}=4.0746 \mathrm{~L} / 100 \mathrm{~m}^{2}$.

The typical ebb-and-flow system includes an elevated, water-tight bench where plants are grown, a fertilizer solution reservoir, and a pump (Schmal returns through a gravity drain at a sufficiently slow rate to allow for absorption (Elliott, 1990). Irrigation frequency can be controlled using timers (Elliott, 1992). Dutch trays, also known as mobile trays, are self-contained mobile ebb-and-flow benches that can easily be moved throughout a greenhouse (Barreto et al., 2015). These trays are manufactured specifically for use in highly automated growing operations (Uva et al., 2000, 2001). While manufactured ebb-and-flow systems are common in commercial greenhouses, similar systems can be easily assembled from inexpensive materials to suit specific needs (Coggeshall and van Sambeek, 2003; Schmal et al., 2007), and may be designed to operate without a pump (Henley et al., 1994) (Fig. 7). For example, Schmal et al. (2007) used manual valves to flood children's swimming pools for production of large deciduous plants in containers.

Flood-floor irrigation is a similar method in which plants are placed directly onto the greenhouse floor, typically made of concrete, and the entire space is flooded through holes in the floor. The floor has a gentle slope to allow the water to drain back to the fertilizer solution tank. This maximizes the proportion of greenhouse space used for production and operates more rapidly, but is often more labor-intensive than standard ebb-andflow bench systems (Biernbaum, 1990; Uva et al., 2000, 2001). A relatively new approach to flood-floor irrigation is the partial saturation ebb-and-flow watering, whereby the fertilizer solution is pumped onto the higher side of a sloped floor and flows down to drain at the low end. This creates a thin film of water on the floor and allows growers more control over how much water the substrate absorbs (Beytes, 2011; Elmer et al., 2012; Gent and McAvoy, 2011). Compared with standard flood-floors, partial saturation systems use less water and fertilizer and produce smaller plants (Gent and McAvoy, 2011).

In the trough-tray system, plants are placed in sloped shallow gutters or troughs. Fertilizer solution is pumped into the higher side of the troughs and runs down to a drain at the lower side and returns to the fertilizer solution tank. Trough-trays are most useful for operations that produce continuously in the same size containers. They 

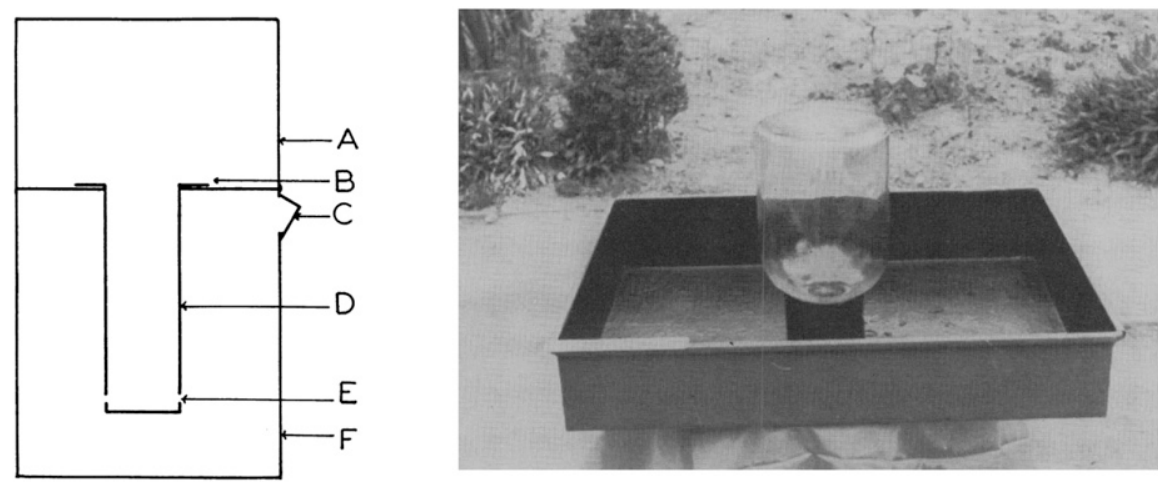

Fig. 4. A double compartment container for subirrigation experiments in plant nutrition. Left: (A) upper compartment, (B) plastic collar, (C) opening for use in filling the lower compartment, $(D)$ plastic tube, $(\mathrm{E})$ perforation, and $(\mathrm{F})$ lower compartment (Johnstone, 1950). Right: Sand-culture equipment coated with aluminum paint with the $1-\mathrm{gal}(3.78 \mathrm{~L})$ bottle reservoir. A $15-\mathrm{cm}(5.9$ inches $)$ ruler on the lower left side indicates size (Johnstone, 1952). Republished with permissions of the American Society of Plant Biologists; permissions conveyed through Copyright Clearance Center Inc.

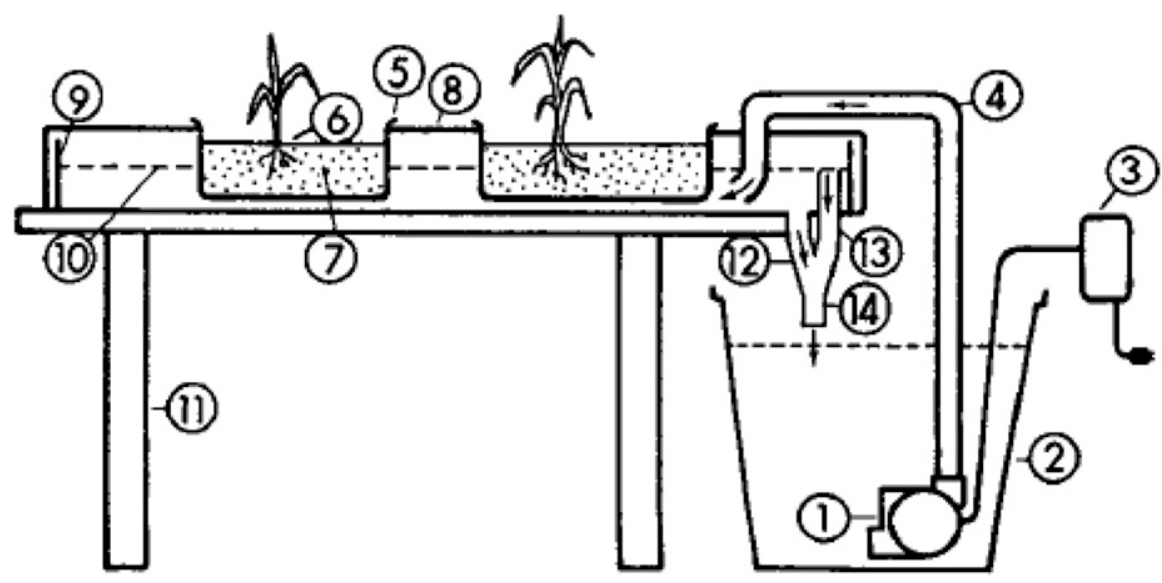

Fig. 5. A fully automatic subirrigation system for greenhouse and growth chamber use: (1) submersible pump, (2) lower storage reservoir, (3) remote timer, (4) opaque rubber hose, (5) container for subirrigation, (6) layer of coarse sand or perlite on the surface to reduce algal growth, (7) rooting medium, (8) plastic cover, (9) upper reservoir, (10) fertilizer solution level, and (11) wooden legs. The solution inflow rate into the upper reservoir is adjusted so that it is greater than the upper reservoir drain flow (12) but less than the drain flow plus the standpipe flow (13). This system employs four identical upper reservoirs; only one is depicted here. Reprinted from Stanwood et al. (1974) with permission from the American Society of Agronomy, Crop Science Society of America, and Soil Science Society of America.

are less versatile than ebb-and-flow benches because they can accommodate only a limited number of plants in relatively small containers, and take up more space for a similar number of plants compared with ebb-and-flow benches because the narrow troughs must be spaced apart. However, trough trays also allow for better air circulation through the canopy because of this spacing (Nelson, 2003).

Other types of subirrigation include wick irrigation and capillary mats. Wick irrigation supplies water and nutrients from a fertilizer solution reservoir to the substrate via an absorptive wick, providing consistent moisture without runoff (Ferrarezi and Testezlaf, 2015; Ferrarezi et al., 2012; Million et al., 2007; Oh et al., 2007; Son et al., 2006). Capillary mats are absorbent mats used to provide potted plants with moisture from below the containers to minimize fluctuations in substrate water content (Morvant et al., 1997; Payne and Adam, 1980; van Iersel and Nemali, 2004). A finely perforated, thin plastic film can be used to cover capillary mats to reduce evaporation and algal growth. Newer capillary mats may also have a liner below the mat, which prevents water from dripping from the mat (e.g., Aquamat; Soleno Textiles, Laval, QC, Canada). Capillary mats are versatile and can be used on a temporary basis and for outdoor production.

\section{Principles underlying subirrigation, substrates, and containers}

Water and nutrients are delivered to plants by the passive movement of water through the substrate due to capillary action (Uva et al., 2001). Substrate physical properties may affect the efficiency of capillary rise. Adequate media stability, density, particle structure, and water holding capacity are needed to allow water movement within the containers (Elia et al., 2003; Oh et al., 2007). Substrates with large particles have large pore spaces, reducing capillary action. Most commonly used soilless substrates are suitable for use with subirrigation (Caron et al., 2005; James and van Iersel, 200la; Oh et al., 2007), and different substrates can be mixed to suit particular needs (Martinez and Silva Filho, 2006).

Container height can also affect subirrigation efficiency because water must travel further to reach the upper part of the substrate in taller containers (Bailey et al., n.d.). Ferrarezi et al. (2015a) have shown that vertical gradients occur in subirrigated containers because water is absorbed by the lower part of the substrate and moves upward. Capillary rise can occur slowly; in $15-\mathrm{cm}$-diameter $\times 12-\mathrm{cm}$-tall pots filled with a peat-perlite substrate, water did not reach the upper substrate layer until up to $20 \mathrm{~h}$ after 'Panama Red' hibiscus (Hibiscus acetosella) plants were subirrigated (Ferrarezi et al., 2015a).

While plastic containers are most common, containers made from biodegradable materials can also be used with subirrigation. Beeks and Evans (2013a, 2013b) compared the effects of using several types of biocontainers for growing cyclamen (Cyclamen persicum) using ebb-and-flow benches over a 15-week production cycle. Shoot dry weight was greater in all biocontainers than in the plastic control 


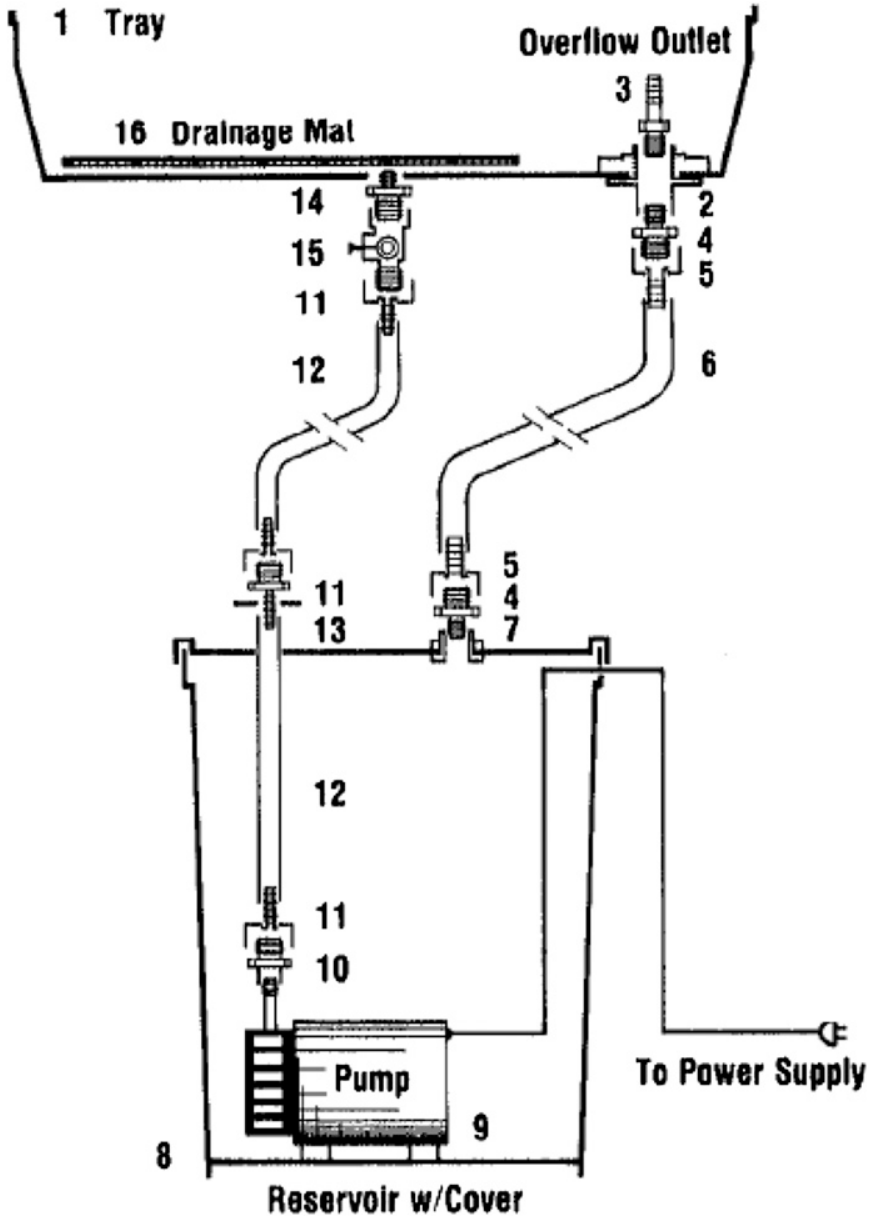

Fig. 6. Schematic diagram of pulsed subirrigation tray system: (1) structural foam tray $(0.36 \times 0.50 \times 0.10 \mathrm{~m}),(2)$ bulkhead fitting $(1 / 2$-inch dual thread $),(3)$ adapter $[1 / 2$-inch male pipe thread $(M P T) \times 1 / 2$-inch barb], (4) adapter $[1 / 2$-inch MPT $\times$ male garden hose thread $($ MHT)], (5) swivel [female garden hose thread $($ FHT) $\times 1 / 2$-inch barb], (6) garden hose (1/2-inch), (7) bulkhead fitting (1/2-inch single thread), $(8)$ bucket $(18 \mathrm{~L})$ with lid, (9) submersible pump with 1/4-inch MPT outlet, (10) adapter (1/4-inch female pipe thread $\times$ MHT), (11) swivel $($ FHT $\times 1 / 4$-inch barb), (12) polyethylene tubing (black 1/4-inch), (13) adapter $($ MHT $\times 1 / 4$-inch barb), (14) adapter $($ MHT $\times 3 / 8$-inch MPT), (15) ball valve (1/4-inch turn), (16) drainage mat; $1 \mathrm{~m}=3.2808 \mathrm{ft}, 1$ inch $=2.54 \mathrm{~cm} .1 \mathrm{~L}=0.2642$ gal. Reprinted from Elliott (1992) with permission from the American Society of Horticultural Science.

pots, with the exception of wood fiber containers. Plants grown in the wood fiber containers had reduced dry weights, presumably because these containers did not have holes in the bottom and water could not easily be absorbed through the walls. These containers also absorbed less nutrient solution per irrigation and had the shortest irrigation interval. Highly porous biocontainers (made from wood fiber, peat, dairy manure, and rice straw) required a higher total volume of nutrient solution over the course of the study because water readily evaporated from the container walls. These containers also had greatly reduced tensile strengths at the end of the production cycle. Bioplastic, rice hull, paper, and coconut fiber containers did not differ from the control containers in irrigation interval or total irrigation volume, and did not have reduced tensile strengths at the end of the production cycle. Koeser et al. (2013) compared ebb-and-flow subirrigation to hand and drip watering using coleus (Solenostemon scutellarioides) grown in several types of biocontainers. Subirrigation improved growth in all treatments, and this effect was attributed to increased fertilization rate due to the absence of leaching. Subirrigation reduced the puncture strength of manure, paper, and wood fiber biocontainers, but not peat biocontainers.

\section{Water conservation}

Subirrigation can be especially beneficial in areas where water scarcity is an issue. Compared with overhead irrigation, subirrigation systems have been consistently shown to reduce overall water use, primarily because excess water is collected and reused (Davis et al., 2008, 2011; Dumroese et al., 2007; Elliott, 1990). For example, Dumroese et al. (2006) found that subirrigation requires $56 \%$ less water than overhead irrigation. Roeber (2010) indicated the different water use for potted plant production, showing that ebb-and-flow benches and troughs use 0.4 to 0.8 $\mathrm{m}^{3} \cdot \mathrm{m}^{-2}$ water per year, drip irrigation use 0.8 to $1.6 \mathrm{~m}^{3} \cdot \mathrm{m}^{-2}$ water per year, and hand or sprinkler irrigation use 1.2 to 2.4 water $\mathrm{m}^{3} \cdot \mathrm{m}^{-2}$ per year. Subirrigation generally uses less water than overhead watering methods mainly because the unused solution is collected for reuse, rather than being lost due to drainage (Lieth and Oki, 2008).

\section{Salinity}

In semiarid regions, growers often rely on saline water sources. Subirrigation can mitigate the effects of osmotic stress that can be induced by applying saline water. Tomato (Solanum lycopersicum) subirrigated with fertilizer solution prepared with saline water had fruit yields comparable to plants drip irrigated with the same solution (Incrocci et al., 2006). Another study demonstrated that subirrigated tomato yields were higher and salt accumulation was minimal when nutrient content of the irrigation solution was reduced by $30 \%$ (Montesano et al., 2010). Subirrigation reduced tomato plant size and overall water use but improved water use efficiency. Accumulated salts were found primarily in the upper substrate layers (Incrocci et al., 2006; Montesano et al., 2010). The accumulation of salts within the substrate prevented the fertilizer solution from becoming overly saline, reducing the need to discharge unusable fertilizer solution, resulting in more efficient water and fertilizer use (Incrocci et al., 2006; Martinetti et al., 2008). In zucchini squash (Cucurbita pepo), subirrigation with moderately saline water reduced growth rate and yield, but improved fruit quality and water use efficiency when compared 

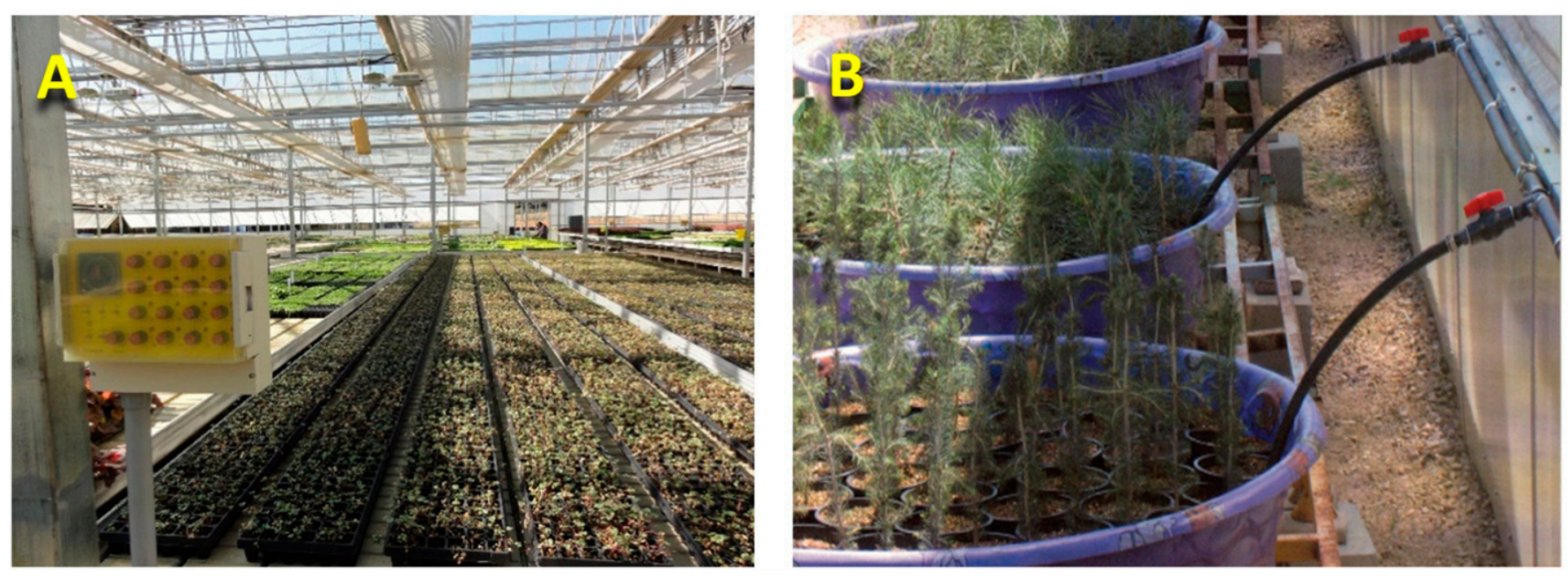

Fig. 7. Types of equipment used in subirrigation. (A) Commercial prefabricated and automated ebb-and-flow benches for ornamental seedling and plant production. Photo courtesy of Midwest GRO Master Inc. (St. Charles, IL). (B) Small swimming pools adapted for large deciduous seedling production in containers (Schmal et al., 2007). (C) 2007 by the Board of Regents of the University of Wisconsin System. Reproduced by the permission of the University of Wisconsin Press.

with subirrigation with nonsaline nutrient solution (Rouphael et al., 2006).

\section{Vegetable and fruit/tree crops}

Currently, subirrigation is primarily used for ornamental plant production (Table 1). However, subirrigation may become an increasingly valuable method for the production of nonornamental crops, such as vegetables (Table 2) and fruit/tree seedlings (Table 3 ).

\section{Fertilization}

Recirculation allows overall fertilizer use to be reduced because no nutrients are lost from the system. However, subirrigation requires careful management of fertilizer solution concentrations to produce high-quality greenhouse crops (Rouphael and Colla, 2005; Zheng et al., 2004). Optimal fertilization rates for overhead irrigation systems are well known, but there is less applied information available about ideal fertilizer solution concentrations for subirrigation (Kang and van Iersel, 2001). Generally, fertilizer concentrations should be lower with subirrigation than with overhead or drip irrigation (Elliott, 1990; Kent and Reed, 1996; van Iersel, 1999). Nutrient salts are not leached from the substrate and can accumulate within the containers, potentially exposing the plants to osmotic stress (Biernbaum, 1988, 1990; Morvant et al., 1997; Uva et al., 1998; Yelanich and Biernbaum, 1988). High salinity occurs mainly in the upper substrate layer because salts move along with the capillary flow. As water evaporates from the surface, the salts accumulate in the top substrate layer (Argo and Biernbaum, 1996; Incrocci et al., 2006; Zheng et al., 2004). The accumulation of salts in the upper substrate layer is exacerbated by high fertilization rates (van Iersel, 2000). However, subirrigated plants are generally unaffected by high salinity in the upper substrate layers (Cox, 2001; Incrocci et al., 2006) because root growth occurs primarily in the lower portions of the container where there is more water available (Kent and Reed, 1996; Montesano et al., 2010; Morvant et al., 1997). In the postproduction environment, accumulated salts from the upper portion of the substrate can potentially be washed to the bottom layers by top watering, but this does not seem to cause serious damage to the plants (van Iersel, 2000). Effective nutrient management for subirrigation requires minimizing the risk of osmotic stress, while providing the plants with adequate nutrition (James and van Iersel, 2001b; Zheng et al., 2004).

Optimal fertilizer solution concentrations vary among species and may depend on both the nutritional requirements and salt tolerance of a particular crop (Kang and van Iersel, 2002). This was demonstrated in a comparison of several bedding plant species subirrigated with various concentrations of Hoagland solution $(12.5 \%$ to $200 \%)$. Full strength (100\% concentration) Hoagland solution has a nitrogen concentration of 210 $\mathrm{mg} \cdot \mathrm{L}^{-1}$ and an EC of $2.0 \mathrm{dS} \cdot \mathrm{m}^{-1}$. Maximum zinnia (Zinnia elegans) and celosia (Celosia argentea) dry weights were observed at a $50 \%$ strength solution, and dry weights, as well as zinnia flower diameter, decreased at higher concentrations. In alyssum (Lobularia maritima) and dianthus (Dianthus chinensis), maximum growth occurred at the $100 \%$ concentration, but dianthus had the most flowers at a $200 \%$ concentration. Gomphrena (Gomphrena globosa) and stock (Matthiola incana) grew best within the $100 \%$ to $200 \%$ range, suggesting that these plants are particularly tolerant of accumulated salts (Kang and van Iersel, 2002). In a similar experiment, salvia (Salvia splendens) growth increased as fertilizer concentration increased from $12.5 \%$ to $100 \%$ Hoagland solution. Shoot dry weight, shoot:root ratio, and leaf area increased, while net photosynthesis, stomatal conductance, and transpiration decreased at higher fertilizer solution concentrations, suggesting that the treatment effects were due to shifts in carbon allocation and more efficient production of leaf area at increased fertilization rates. Leaf area decreased when fertilizer concentration was increased to $200 \%$ (Kang and van Iersel, 2004). Comparable effects of fertilizer solution concentration on plant growth were also observed in subirrigated pansy [Viola $\times$ wittrockiana (Kang and van Iersel, 2002)] and wax begonia [Begonia xsemperflorens- 
Table 1. Selected publications related to subirrigation for ornamental plant production.

\begin{tabular}{|c|c|c|c|}
\hline Subirrigation type $\mathrm{z}^{\mathrm{z}}$ & Species & Summary $^{\mathrm{y}}$ & Source \\
\hline $\begin{array}{l}\text { Ebb-and-flow benches } \\
\qquad(1 \times 1 \times 0.15 \mathrm{~m})\end{array}$ & Cyclamen (Cyclamen persicum) & $\begin{array}{l}\text { Plants grown in several types of } \\
\text { biocontaners had higher shoot dry } \\
\text { weights than those grown in plastic } \\
\text { pots }\end{array}$ & $\begin{array}{l}\text { Beeks and Evans } \\
\quad(2013 a, 2013 b)\end{array}$ \\
\hline $\begin{array}{l}\text { Ebb-and-flow troughs } \\
\qquad\left(5 \mathrm{~m}^{2}\right)\end{array}$ & $\begin{array}{l}\text { Chrysanthemum (Dendranthema } \\
\text { indicum) }\end{array}$ & $\begin{array}{l}\text { Used subirrigation to root } \\
\text { chrysanthemum cuttings. Root growth } \\
\text { was inversely correlated to substrate } \\
\text { water content between waterings }\end{array}$ & Buwalda et al. (1995 \\
\hline $\begin{array}{l}\text { Hand-watered plant } \\
\text { saucers }(0.195 \mathrm{~m} \\
\text { diameter })\end{array}$ & Poinsettia (Euphorbia pulcherrima) & $\begin{array}{l}\text { Subbirigation was compared with } \\
\text { overhead watering. There was no } \\
\text { difference in plant height or bract size, } \\
\text { but subirrigated plants had lower dry } \\
\text { weights and diameters }\end{array}$ & Cox $(2001)$ \\
\hline $\begin{array}{l}\text { Hand-watered trays } \\
\qquad(0.5 \times 0.35 \times 0.06 \mathrm{~m}) \\
\text { lined with } 6 \text {-mil } \\
\text { black plastic }\end{array}$ & Rhododendron (Rhododendron sp.) & $\begin{array}{l}\text { Hardwood stem cuttings had large root } \\
\text { balls and a higher rooting percentage } \\
\text { in lower } \mathrm{pH} \text { media }\end{array}$ & Holt et al. (1998) \\
\hline $\begin{array}{l}\text { Ebb-and-flow benches } \\
\qquad(2.4 \times 1.2 \mathrm{~m})\end{array}$ & $\begin{array}{l}\text { Petunia }(\text { Petunia } \times \text { bybrida }) \text { and wax } \\
\text { begonia }(\text { Begonia } \times \text { semperflorens } \\
\text { cultorum })\end{array}$ & $\begin{array}{l}\text { Good growth and flowering over wide } \\
\text { range of fertilizer solution } \\
\text { concentrations, little effect of different } \\
\text { substrates }\end{array}$ & $\begin{array}{l}\text { James and van Iersel } \\
\qquad(2001 b)\end{array}$ \\
\hline $\begin{array}{l}\text { Ebb-and-flow benches } \\
\qquad(2.4 \times 1.2 \mathrm{~m})\end{array}$ & Petunia & $\begin{array}{l}\text { Optimal fertilizer electrical conductivity } \\
\text { (EC) decreases as temperature } \\
\text { increases. Maintaining optimal } \\
\text { leachate EC is better than maintaining } \\
\text { constant fertilizer solution EC }\end{array}$ & $\begin{array}{l}\text { Kang and van Iersel } \\
\qquad(2001)\end{array}$ \\
\hline $\begin{array}{l}\text { Ebb-and-flow benches } \\
\qquad(2.4 \times 1.2 \mathrm{~m})\end{array}$ & Salvia (Salvia splendens) & $\begin{array}{l}\text { High fertilizer concentrations increase } \\
\text { the shoot:root ratio and hasten } \\
\text { flowering }\end{array}$ & $\begin{array}{l}\text { Kang and van Iersel } \\
\qquad(2004)\end{array}$ \\
\hline $\begin{array}{l}\text { Ebb-and-flow benches } \\
\qquad(2.4 \times 1.2 \mathrm{~m})\end{array}$ & Petunia and wax begonia & Optimal leachate EC is 1.0 to $1.7 \mathrm{dS} \cdot \mathrm{m}^{-1}$ & $\begin{array}{l}\text { Kang and van Iersel } \\
\qquad(2009)\end{array}$ \\
\hline $\begin{array}{l}\text { Ebb-and-flow trays } \\
\qquad(1 \times 1.1 \mathrm{~m})\end{array}$ & $\begin{array}{l}\text { New guinea impatiens (Impatiens } \\
\text { walleriana) and peace lily } \\
\text { (Spathiphyllum wallisii) }\end{array}$ & $\begin{array}{l}\text { Growth was most vigorous at } 8 \mathrm{~mm} \\
\text { nitrogen }(\mathrm{N}) \text { for new guinea impatiens } \\
\text { and } 10 \mathrm{~mm} \text { for peace lily, and } \\
\text { declined thereafter. EC was two to five } \\
\text { times higher in the upper substrate in } \\
\text { all treatments }\end{array}$ & $\begin{array}{l}\text { Kent and Reed } \\
\quad(1996)\end{array}$ \\
\hline $\begin{array}{l}\text { Ebb-and-flow benches } \\
\text { (dimensions not } \\
\text { available) }\end{array}$ & $\begin{array}{l}\text { Areca palm (Dypsis lutescens) and } \\
\text { philodendron (Philodendron sp.) }\end{array}$ & $\begin{array}{l}\text { Compared with overhead watering, } \\
\text { subirrigation used } 10 \text { times less water } \\
\text { per unit area }\end{array}$ & $\begin{array}{l}\text { Klock-Moore and } \\
\text { Broschat }(2000)\end{array}$ \\
\hline $\begin{array}{l}\text { Ebb-and-flow benches } \\
\text { (dimensions not } \\
\text { available) }\end{array}$ & Petunia & $\begin{array}{l}\text { Subirrigated plants grew larger than } \\
\text { overhead-watered plants at several } \\
\text { rates of controlled release fertilizer } \\
\text { incorporation. With liquid fertilizer, } \\
\text { subirrigated plants were larger at } 100 \\
\text { ppm N, but smaller at } 150 \mathrm{ppm} \mathrm{N}\end{array}$ & $\begin{array}{l}\text { Klock-Moore and } \\
\text { Broschat }(2001)\end{array}$ \\
\hline
\end{tabular}


Table 1. (Continued) Selected publications related to subirrigation for ornamental plant production.

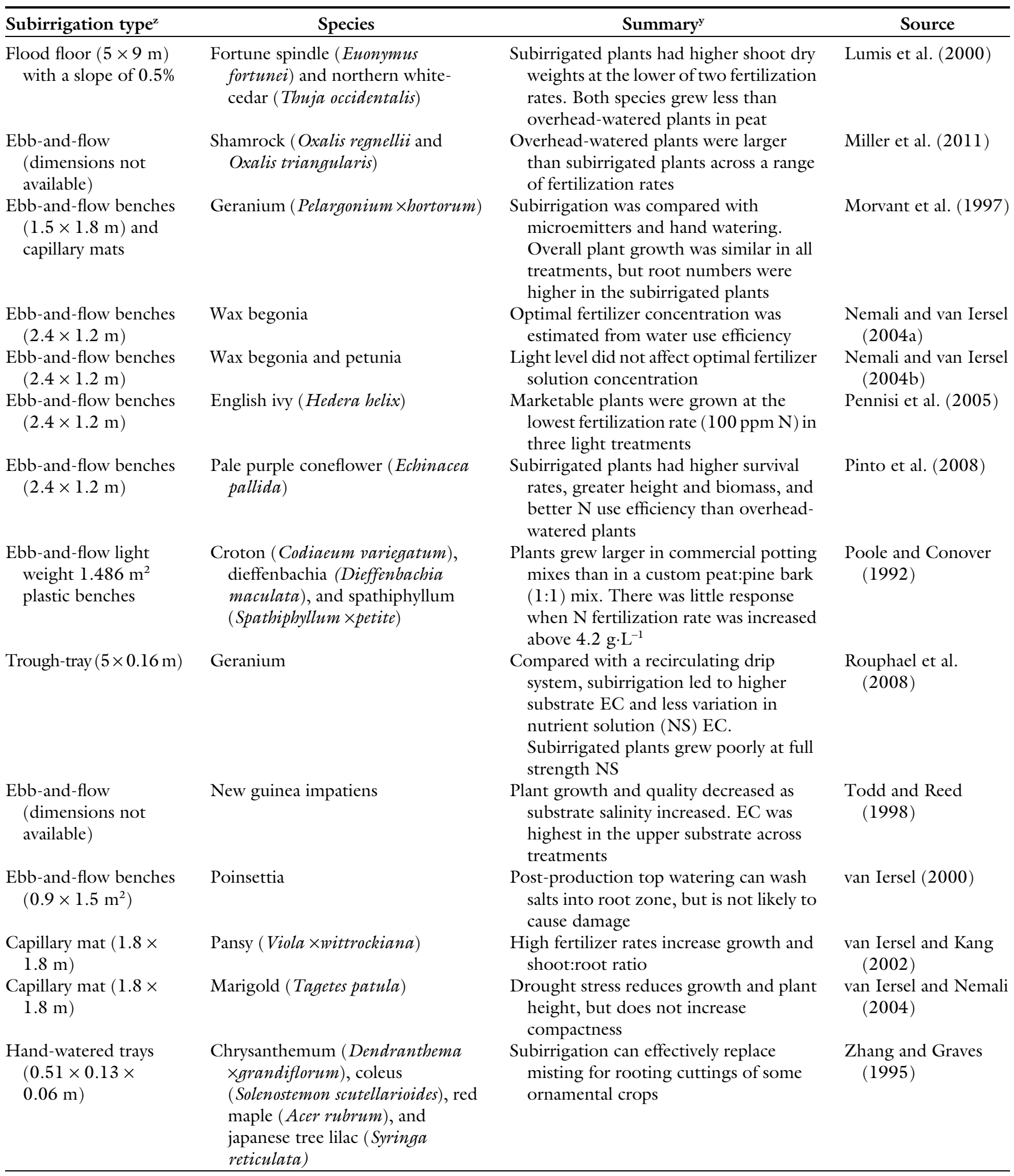

${ }^{\mathrm{z}}$ Dimensions in length $\times$ width $\times$ height; $1 \mathrm{~m}=3.2808 \mathrm{ft}, \mathrm{l} \mathrm{m}^{2}=10.7639 \mathrm{ft}^{2}, \mathrm{l} \mathrm{mil}=0.0254 \mathrm{~mm}$.

${ }^{\mathrm{y}} \mathrm{l} \mathrm{dS} \cdot \mathrm{m}^{-1}=1 \mathrm{mmho} / \mathrm{cm}, 1 \mathrm{ppm}=1 \mathrm{mg} \cdot \mathrm{L}^{-1}, 1 \mathrm{~g} \cdot \mathrm{L}^{-1}=0.1335 \mathrm{oz} / \mathrm{gal}$.

cultorum (Nemali and van Iersel, 2004a)]. However, Zheng et al. (2004) found that fertilizer solution concentration had no effect on leaf area of subirrigated gerbera (Gerbera jamesonii) during the final production stage. Growth decreased when subirrigation fertilizer concentrations exceeded an optimum concentration in subirrigated poinsettia [Euphorbia pulcherrima (Dole et al., 1994)], new guinea impatiens [Impatiens $\times$ hawkeri 
Table 2. Selected publications related to subirrigation for vegetable production.

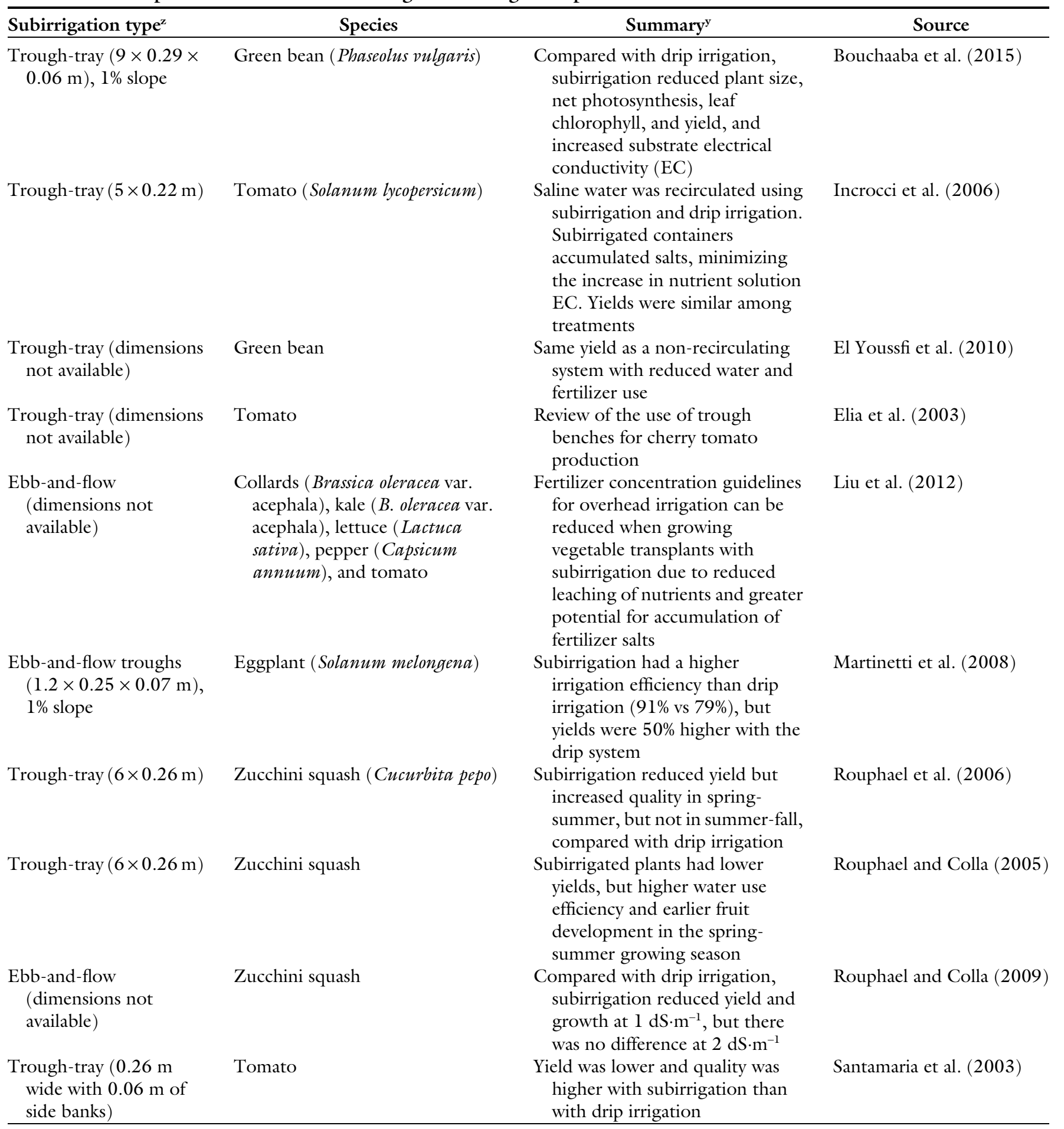

${ }^{\mathrm{z}}$ Dimensions in length $\times$ width $\times$ height; $1 \mathrm{~m}=3.2808 \mathrm{ft}$.

${ }^{\mathrm{y}} 1 \mathrm{dS} \cdot \mathrm{m}^{-1}=1 \mathrm{mmho} / \mathrm{cm}$.

(Kent and Reed, 1996)], wax begonia (Nemali and van Iersel, 2004a, 2004b), petunia [Petunia $\times$ hybrida (James and van Iersel, 2001b)], miniature rose [Rosa chinensis minima (Zheng et al., 2010 ); collards (Brassica oleracea var. acephala), kale (B. oleracea var. acephala), lettuce (Lactuca sativa), pepper (Capsicum annumm), and tomato transplants (Liu et al., 2012); and shamrock species [Oxalis regnellii and O. triangularis (Miller et al., 2011)].

\section{Agrochemicals}

Subirrigation allows pesticides and plant growth regulators (PGRs) to be applied to plants along with the fertilizer solution. Such applications should only be made if the label specifically allows for application by subirrigation. Using subirrigation to apply pesticides and PGRs ensures uniform application, prevents the release of these chemicals to the environment, and can further reduce labor costs as well as minimize employee exposure to pesticides (Million et al., 1999, 2002; van Iersel et al., 2000, 
Table 3. Selected publications related to subirrigation for fruit/tree seedling production.

\begin{tabular}{|c|c|c|c|}
\hline Subirrigation type $\mathrm{e}^{\mathrm{z}}$ & Species & Summary & Source \\
\hline $\begin{array}{l}\text { Ebb-and-flow trays } \\
\qquad(1.22 \times 1.22 \mathrm{~m})\end{array}$ & Northern red oak (Quercus rubra) & $\begin{array}{l}\text { Under fertilized conditions, } \\
\text { subirrigated seedlings had } \\
\text { greater biomass and field } \\
\text { diameter growth than top- } \\
\text { watered plants }\end{array}$ & $\begin{array}{l}\text { Bumgarner et al. } \\
\qquad(2008)\end{array}$ \\
\hline $\begin{array}{l}\text { Subirrigation (dimensions } \\
\text { not available) }\end{array}$ & $\begin{array}{c}\text { Eucalyptus (Eucalyptus grandis, Eucalyptus } \\
\text { urophylla, and E. grandis } \times \text { E. urophylla) }\end{array}$ & $\begin{array}{l}\text { Subirrigation increased the } \\
\text { number of cuttings on clonal } \\
\text { plants }\end{array}$ & $\begin{array}{l}\text { Cunha et al. } \\
\text { (2009a, 2009b); } \\
\text { Ribeiro et al. } \\
(2014)\end{array}$ \\
\hline $\begin{array}{l}\text { Ebb-and-flow benches } \\
\qquad(2.44 \times 1.22 \times 0.115 \mathrm{~m})\end{array}$ & Koa (Acacia koa) & $\begin{array}{l}\text { Subirrigated and overhead- } \\
\text { watered seedlings had similar } \\
\text { growth and vigor }\end{array}$ & $\begin{array}{l}\text { Dumroese et al. } \\
\qquad(2011)\end{array}$ \\
\hline $\begin{array}{l}\text { Subirrigation system } \\
\qquad(3.75 \times 0.85 \mathrm{~m}) \text { with } \\
\text { expanded clay }\end{array}$ & Coffee (Coffea arabica) & $\begin{array}{l}\text { Adequate plant growth, } \\
\text { regardless of the fertilization } \\
\text { level of the stock plant }\end{array}$ & $\begin{array}{l}\text { Laviola et al. } \\
\qquad(2007)\end{array}$ \\
\hline $\begin{array}{l}\text { Subirrigation trays } \\
\qquad(0.62 \times 0.41 \times 0.15 \mathrm{~m})\end{array}$ & Rangpur lime & $\begin{array}{l}\text { Validation of subirrigation } \\
\text { technology for citrus } \\
\text { rootstock production }\end{array}$ & Salvador (2010) \\
\hline
\end{tabular}

${ }^{2}$ Dimensions in length $\times$ width $\times$ height; $1 \mathrm{~m}=3.2808 \mathrm{ft}$.

2001). A potential problem with applying agrochemicals via subirrigation is that excess solution drains back into the holding tank. Contamination can be prevented by using separate holding tanks for agrochemicals, but this may be expensive. However, residual concentrations of PGRs in fertilizer solutions, such as paclobutrazol and uniconazole, were shown to be very low after application via subirrigation (Adriansen and Odgaard, 1997; Million et al., 1999). Another consideration in applying agrochemicals through subirrigation is the substrate moisture level: drier substrate absorbs more solution, and thus agrochemical, than wetter substrates (van Iersel et al.,
2000). Subirrigation has also been used for applying natural PGRs such as tea seed (Camellia sp.) powder (Andresen and Cedergreen, 2010). Imidacloprid (Marathon $60 \mathrm{WP}$; OHP, Mainland, PA) applied via subirrigation to poinsettias was more effective at controlling silverleaf whiteflies (Bemisia argentifolii) than drench applications (van Iersel et al., 2000). Although drench applications resulted in faster initial uptake of the imidacloprid, subirrigation application resulted in higher leaf concentrations of imidacloprid after $63 \mathrm{~d}$ and better long-term control. Applications by subirrigation appeared to allow for plant uptake of imidacloprid over a longer period, resulting in more uniform distribution of the insecticide throughout the plant, as compared with drip irrigated plants treated with an imidacloprid drench (van Iersel et al., 2001).

\section{Pathology}

Transmission of root-infesting pathogens between containers or benches through recirculated irrigation water is a potential drawback of subirrigation (Sanogo and Moorman, 1993; Stanghellini et al., 2000; van der Gaag et al., 2001; Watanabe et al., 2008). Oomycetes of the genera Pythium and Phytophthora are particularly problematic, since they produce large numbers of highly mobile 
aquatic zoospores and seriously affect plant growth and quality (Sanogo and Moorman, 1993; Stanghellini et al., 2000; Thinggaard and Middelboe, 1989). Bacteria, viruses, and fungal pathogens can also migrate through the recirculating system and infect new hosts. Several measures can be taken to reduce the pathogen load of recirculated water. Infectious propagules can easily enter the reservoir with plant debris, and removal of dead material helps minimize disease spread (Atmatjidou et al., 1991; Bauerle, 1990). Filtering the fertilizer solution can also prevent contamination, removing extant microbes and preventing future infections (Atmatjidou et al., 1991; Garibaldi et al., 2003; Martínez et al., 2010; Runia, 1995; Stewart-Wade, 2011). Membrane filters effectively remove pathogens, but are expensive and require frequent replacement (Runia, 1995; Stewart-Wade, 2011). Slow media filtration is the passing of recirculated irrigation water through an inert media, most commonly sand, at a low flow rate. This process eliminates most plant pathogens through a combination of mechanical filtration and biological activity, but may be impractical because it requires a large amount of space, may not consistently provide adequate filtration, is relatively slow, and can support microbial populations that include human pathogens (Stewart-Wade, 2011). Recirculated fertilizer solution can also be treated using ozone or ultraviolet radiation to eliminate pathogens (Martínez et al., 2010; Runia, 1995; Stewart-Wade, 2011). However, in a survey of greenhouses and nurseries, Meador et al. (2012) found that recirculating fertilizer solution from subirrigation systems, on average, did not meet recommended standards for horticultural water quality, and that microbial counts were exceptionally high. The spread of disease among containers in subirrigation systems is an important practical concern and more effective and economical preventative methods are needed.

Limiting the duration of flooding events or the amount of fertilizer solution provided to subirrigated plants may prevent or minimize disease spread. Partial saturation ebband-flow watering rapidly delivers water to plants. With this method, less water is absorbed by the substrate per flooding event. Elmer et al. (2012) demonstrated that partial saturation can prevent the spread of pythium root rot (Pythium sp.) infections. This may be because less fertilizer solution drains out of the containers following irrigation, fewer pathogens survive in the drier substrate, or partial saturation may provide plant root zone with more oxygen (Gent and McAvoy, 2011).

\section{Sensor-based subirrigation control}

Subirrigation is typically controlled using timers according to a predetermined schedule, usually designed to meet operational needs. Sensors can be used to monitor substrate moisture (Nemali and van Iersel, 2006) and control subirrigation based on plant water use. For a review of the use of different sensors in irrigation control, see van Iersel et al. (2013). Subirrigation has been successfully automated using tensiometers (Montesano et al., 2010; Rouphael and Colla, 2009; Rouphael et al., 2006, 2008), lysimeters (Melo et al., 2013), and capacitance moisture sensors (Ferrarezi et al., 2013, 2014, 2015a, 2015b). Electronic switches connected to tensiometers to begin and end irrigation events at -5 and $-1 \mathrm{kPa}$ substrate matric potential (high and low media tension values, respectively) in drip and trough-tray irrigated containers were tested in several studies (Rouphael et al., 2008; Rouphael and Colla, 2009). Subirrigation with a standard nutrient solution decreased growth rate and yield of zucchini squash during the spring-summer growing season, but not during the summer-fall growing season compared with the automated drip system (Rouphael and Colla, 2005). When squash plants were irrigated with fertilizer solutions made with saline water, tensiometer-controlled subirrigation decreased yield, but improved fruit quality and increased water use efficiency (Rouphael et al., 2006). Another study used this automation with nonsaline water and showed that tensiometer-controlled subirrigation resulted in zucchini squash fruit yields equal to drip irrigation when fullstrength fertilizer solution was used. However, use of half-strength fertilizer solutions reduced yield more with subirrigation than with drip irrigation (Rouphael and Colla, 2009). With zonal geranium (Pelargonium $\times$ bortorum) grown in the spring and fall at half- and fullstrength fertilizer solutions, subirrigation only reduced growth when full-strength solution was used during the spring (Rouphael et al., 2008). In a similar comparison, Montesano et al. (2010) found that drip irrigated plants used more water and were larger than plants grown in trough-trays when irrigation was automatically triggered at $-7 \mathrm{kPa}$. However, when relatively low fertilizer concentrations were used, subirrigation resulted in equal yields as open-cycle drip irrigation. Triggering irrigation based on specific substrate moisture levels cannot only reduce water use, it can also be used to control plant vigor, potentially reducing the need for plant growth retardant applications (Ferrarezi et al., 2015a, 2015b). Inexpensive open-source microcontrollers can be used to build low-cost automated irrigation controllers (Ferrarezi et al., 2015c).

\section{Economic benefits of subirrigation}

While fertilizer and water use can be reduced with subirrigation, this alone may not be sufficient to offset the initial price of installing an automated subirrigation system, which is often high (Uva et al., 2001). The primary economic benefit of subirrigation is that, by facilitating automation, it reduces the cost of labor, which is the greatest expenditure for many producers (Biernbaum, 1990; USDA, 2009; Uva et al., 1998, 2000, 2001). Compared with traditional overhead watering, subirrigation may also improve plant health and quality. The incidence and spread of foliar disease is reduced because the leaves are not wetted during irrigation (Rouphael et al., 2006; Zheng et al., 2004). Furthermore, subirrigated crops are typically uniform, because water and nutrients are evenly distributed, and uniformity makes handling and shipping easier (Biernbaum, 1990; Giacomelli and Ting, 1999).

\section{Conclusions}

Subirrigation is a reliable method of growing high-quality plants with minimal environmental impact. Recycling and reuse of unused fertilizer 
solution prevents the unwanted release of nutrient-rich runoff into the environment, which helps growersmeet environmental regulations. Subirrigation is currently used largely for ornamental plants, but has recently been used for other crops such as vegetables and fruit/tree seedlings. The use of subirrigation for vegetables may be particularly beneficial for regions with water scarcity or poor-quality, saline irrigation water. Fertilization rates can generally be lower for subirrigated plants than for overhead- or drip irrigated plants, resulting in fertilizer savings, and thus an economic benefit for growers. Perhaps the biggest challenge related to subirrigation is the potential spread of pathogens. Design modifications to subirrigation systems may help prevent this. Sensorbased irrigation control has recently been applied to subirrigation, and may be used to further improve nutrient and water use efficiencies, as well as plant quality, in subirrigation systems.

\section{Literature cited}

Adriansen, E. and P. Odgaard. 1997. Residues of paclobutrazol and uniconazole in nutrient solutions from ebb and flood irrigation of pot plants. Sci. Hort. 69:73-83.

Aiello, A.S. and W.R. Graves. 1998. Success varies when using subirrigation instead of mist to root softwood cuttings of woody taxa. J. Environ. Hort. 16:42-46.

Andresen, M. and N. Cedergreen. 2010. Plant growth is stimulated by tea-seed extract: A new natural growth regulator? HortScience 45:1848-1853.

Argo, W.R. and J.A. Biernbaum. 1996. The effect of lime, irrigation-water source, and water-soluble fertilizer on root-zone $\mathrm{pH}$, electrical conductivity, and macronutrient management of container root media with impatiens. J. Amer. Soc. Hort. Sci. 121:442-452.

Atmatjidou, V.P., R.P. Fynn, and H.A.J. Hoitink. 1991. Dissemination and transmission of Xanthomonas campestris pv. begoniae in an ebb and flow irrigation system. Plant Dis. 75:1261-1265.

Bailey, D.A., W.C. Fonteno, and P.V. Nelson. Undated. Greenhouse Substrates and Fertilization. 4 Dec. 2014. <www.ces. ncsu.edu/depts/hort/floriculture/ plugs/ghsubfert.pdf $>$.

Barreto, C.V.G. 2011. Use of capillary irrigation growing Citrus limonia L. in small recipients. Univ. Campinas, Campinas, Brazil, PhD Diss.
Barreto, C.V.G., R.S. Ferrarezi, F.B. Arruda, and R. Testezlaf. 2015. Growth and physiological responses of rangpur lime seedlings irrigated by a prototype subirrigation tray. HortScience 50:123-129.

Bauerle, B. 1990. Keep an open mind about closed loop. Greenhouse Grower $8: 53-58$.

Beeks, S.A. and M.R. Evans. 2013a. Growth of cyclamen in biocontainers on an ebb-and-flood subirrigation system. HortTechnology 23:173-176.

Beeks, S.A. and M.R. Evans. 2013b. Physical properties of biocontainers used to grow long-term greenhouse crops in an ebb-and-flood irrigation system. HortScience 48:732-737.

Beytes, C. 2011. A New Slant on Subirrigation. 24 July 2011. <http://www. ballpublishing.com / growertalks / ViewArticle.aspx?articleid=18504>.

Biekart, H.M. and C.H. Connors. 1935. The greenhouse culture of carnations in sand. New Jersey Agr. Expt. Sta., New Brunswick, NJ.

Biernbaum, J.A. 1988. Evaluation of subirrigation systems for interior plants. HortScience 23:752 (abstr.).

Biernbaum, J.A. 1990. Get ready for subirrigation. Greenhouse Grower 8:130-133.

Bouchaaba, Z., P. Santamaria, R. ChoukrAllah, N. Lamaddalena, and F.F. Montesano. 2015. Open-cycle drip vs closed-cycle subirrigation: Effects on growth and yield of greenhouse soilless green bean. Sci. Hort. 182:77-85.

Bumgarner, M.L., K.F. Salifu, and D.F. Jacobs. 2008. Subirrigation of Quercus rubra seedlings: Nursery stock quality, media chemistry, and early field performance. HortScience 43:2179-2185.

Buwalda, F., R. Frenck, B. Löbker, B. van den Berg-De Vos, and K.S. Kim. 1995. Ebb and flow cultivation of chrysanthemum cuttings in different growing media. Acta Hort. 401:193-200.

Caron, J.E., D.E. Beeson, and R. Boudreau. 2005. Defining critical capillary rise properties for growing media in nurseries. Soil Sci. Soc. Amer. J. 69:794-806.

Chapman, H.D. and G.F. Liebig, Jr. 1938. Adaptation and use of automatically operated sand-culture equipment. J. Agr. Res. 56:73-80.

Coggeshall, M.V. and J.W. van Sambeek. 2003. Designing and Testing a Subirrigation System for Rooting Hardwood Cuttings. Proc. 13th Central Hardwood Forest Conf. NC-234. St. Paul, MN, U.S. Dept. Agr., For. Serv. Gen. Tech. Rpt. 13:415-420.
Cox, D.A. 2001. Growth, nutrient content, and growth medium electrical conductivity of poinsettia irrigated by subirrigation or from overhead. J. Plant Nutr. 24:523-533.

Cunha, A.C., H.N. Paiva, N.F. Barros, H.G. Leite, and F.P. Leite. 2009a. Relationship of mini-stumps nutritional state to number of eucalypt mini-cuttings. Rev. Bras. Cienc. Solo 33:591-599.

Cunha, A.C., H.N. Paiva, H.G. Leite, N.F. Barros, and F.P. Leite. 2009b. Relation of climate variables with eucalypt minicutting production and rooting. Revista Árvore 33:195-203.

Davis, A.S., D.F. Jacobs, R.P. Overton, and R.K. Dumroese. 2008. Influence of irrigation method and container type on northern red oak seedling growth and media electrical conductivity. Native Plants J. 9:4-12.

Davis, A.S., J.R. Pinto, and D.F. Jacobs. 2011. Early field performance of Acacia koa seedlings grown under subirrigation and overhead irrigation. Native Plants J. 12:94-99.

Dole, J.M., J.C. Cole, and S.L. von Broembsen. 1994. Growth of poinsettias, nutrient leaching, and water-use efficiency respond to irrigation methods. HortScience 29:858-864.

Dumroese, R.K., A.S. Davis, and D.F. Jacobs. 2011. Nursery response of Acacia koa seedlings to container size, irrigation method, and fertilization rate. J. Plant Nutr. 34:877-887.

Dumroese, R.K., D.F. Jacobs, A.S. Davis, J.R. Pinto, and T.D. Landis. 2007. An Introduction to Subirrigation in Forest and Conservation Nurseries and Some Preliminary Results of Demonstrations. U.S. Dept. Agr., For. Serv. Proc. RMRSP-50:20-26.

Dumroese, R.K., J.R. Pinto, D.F. Jacobs, A.S. Davis, and B. Horiuchi. 2006. Subirrigation reduces water use, nitrogen loss, and moss growth in a container nursery. Native Plants J. 7:253.

Eaton, F.M. 1931. A large sand culture apparatus. Soil Sci. 31:235-241.

Eaton, F.M. 1936. Automatically operated sand-culture equipment. J. Agr. Res. 53:433-444.

Eaton, F.M. 1941. Plant culture equipment. Plant Physiol. 16:385-392.

El Youssfi, L., R. Choukr-Allah, P. Santamaria, and F.F. Montesano. 2010. Soilless closed cycle production of green bean (Phaseolus vulgaris) using subirrigation: Effects on yield, fruit quality, substrate and nutrient solution parameters. Acta Hort. 938:383390. 
Elia, A., A. Parente, F. Serio, and P. Santamaria. 2003. Some aspects of trough benches system and its performances in cherry tomato production. Acta Hort. 614:161166.

Elliott, G.C. 1990. Reduce water and fertilizer with ebb and flow. Greenhouse Grower 8:70-73.

Elliott, G.C. 1992. A pulsed subirrigation system for small plots. HortScience 27:7172.

Elmer, W.H., M.P.N. Gent, and R.J. McAvoy. 2012. Partial saturation under ebb and flow irrigation suppresses pythium root rot of ornamentals. Crop Prot. 33:29-33.

Ferrarezi, R.S. 2013. Water and nutritional management for rangpur lime production in subirrigation benches automated by capacitance sensors. Univ. Campinas, Campinas, Brazil, PhD Diss.

Ferrarezi, R.S. and R. Testezlaf. 2015. Performance of wick irrigation system using self-compensating benches with substrates for lettuce production. J. Plant Nutr. (In press)

Ferrarezi, R.S., L.N.S. Santos, A.C.M. Sousa, F.F.S. Pereira, M.L.C. Elaiuy, U. Torrel, and E.E. Matsura. 2012. Water depth, filling time and volume of wick irrigation equipment and determination of water distribution uniformity in substrates. Bragantia 71: 273-281.

Ferrarezi, R.S., M.D. Ribeiro, M.W. van Iersel, and R. Testezlaf. 2013. Subirrigation controlled by capacitance sensors for citrus rootstock production. HortScience 48:S142 (abstr.).

Ferrarezi, R.S., M.W. van Iersel, and R. Testezlaf. 2014. Subirrigation automated by capacitance sensors for salvia production. Horticultura Brasileira 32:314-320.

Ferrarezi, R.S., M.W. van Iersel, and R. Testezlaf. 2015a. Monitoring and controlling ebb-and-flow subirrigation with soil moisture sensors. HortScience 50:447453.

Ferrarezi, R.S., M.W. van Iersel, and R. Testezlaf. 2015b. Plant growth response of subirrigated salvia 'Vista Red' to increasing water heights at two substrates. Horticultura Brasileira (In press).

Ferrarezi, R.S., S.K. Dove, and M.W. van Iersel. $2015 \mathrm{c}$. An automated system for monitoring soil moisture and controlling irrigation using low-cost open-source microcontrollers. HortTechnology 25:110118.

Garibaldi, A., A. Minuto, V. Grasso, and M.L. Gullino. 2003. Application of selected antagonistic strains against $P h y$ tophthora cryptogea on gerbera in closed soilless systems with disinfection by slow sand filtration. Crop Prot. 22:10531061 .

Gent, M.P.N. and R.J. McAvoy. 2011 Water and nutrient uptake and use efficiency with partial saturation ebb and flow watering. HortScience 46:791-798.

Gericke, W.F. 1921. Root development of wheat seedlings. Bot. Gaz. 72:404406.

Gericke, W.F. 1922. "Magnesia injury” of plants grown in nutrient solutions. Bot. Gaz. 74:110-113.

Gericke, W.F. 1937. Hydroponics-Crop production in liquid culture media. Science 85:177 (abstr.).

Giacomelli, G.A. and K.C. Ting. 1999 Horticultural and engineering considerations for the design of integrated greenhouse plant production systems. Acta Hort. 481:475-482.

Green, W.J. and E. Green. 1895. Subirrigation in the greenhouse. Ohio Agr. Expt. Sta. Wooster, OH, Bul. 61.

Henley, R.W., U. Bednarzik, and C.A Neal. 1994. Evaluation of a unique greenhouse subirrigation system with two container systems. Southern Nursery Assn. Res. Conf. 39:399-402

Holt, T.A., B.K. Maynard, and W.A. Johnson. 1998. Low $\mathrm{pH}$ enhances rooting of stem cuttings of rhododendron in subirrigation. J. Environ. Hort. 16:4-7.

Incrocci, L., F. Malorgio, A. Della Bartola, and A. Pardossi. 2006. The influence of drip irrigation or subirrigation on tomato grown in closed-loop substrate culture with saline water. Sci. Hort. 107:365-372.

James, E.C. and M.W. van Iersel. 200la Ebb and flow production of petunias and begonias as affected by fertilizers with different phosphorus content. HortScience 36:282-285.

James, E.C. and M.W. van Iersel. 2001b. Fertilizer concentration affects growth and flowering of subirrigated petunias and begonias. HortScience 36:40-44.

Johnstone, G.R. 1950. Simplified equipment for subirrigation experiments in plant nutrition. Plant Physiol. 25:185186.

Johnstone, G.R. 1952. Further studies in the simplification of equipment for subirrigation experiments in plant nutrition. Plant Physiol. 27:405-407.

Kang, J.G. and M.W. van Iersel. 2001. Interactions between temperature and fertilizer concentration affect growth of subirrigated petunias. J. Plant Nutr. 24: $753-765$.

Kang, J.G. and M.W. van Iersel. 2002. Nutrient solution concentration affects growth of subirrigated bedding plants. J. Plant Nutr. 25:387-403.

Kang, J.G. and M.W. van Iersel. 2004. Nutrient solution concentration affects shoot:root ratio, leaf area ratio, and growth of subirrigated salvia (Salvia splendens). HortScience 39:49-54.

Kang, J.G. and M.W. van Iersel. 2009. Managing fertilization of bedding plants: A comparison of constant fertilizer concentrations versus constant leachate electrical conductivity. HortScience 44:151156.

Kang, J.G., M.W. van Iersel, and K.S. Nemali. 2004. Fertilizer concentration and irrigation method affect growth and fruiting of ornamental pepper. J. Plant Nutr. 27:867-884.

Kent, M.W. and D.W. Reed. 1996. Nitrogen nutrition of new guinea impatiens 'Barbados' and spathiphyllum 'Petite' in a subirrigation system. J. Amer. Soc. Hort. Sci. 121:816-819.

Klock-Moore, K.A. and T.K. Broschat. 2000. Use of subirrigation to reduce fertilizer runoff. Proc. Florida State Hort. Soc. 113:149-151.

Klock-Moore, K.A. and T.K. Broschat. 2001. Irrigation systems and fertilizer affect petunia growth. HortTechnology 11:416-418

Koeser, A., G. Kling, C. Miller, and D. Warnock. 2013. Compatibility of biocontainers in commercial greenhouse production. HortTechnology 23:173-176.

Laviola, B.G., H.E.P. Martinez, and A.L. Mauri. 2007. Influence of the level of fertilization of the matrix plants in the formation of seedlings of coffee plants in hydroponic systems. Ciência e Agrotecnologia 31:1043-1047.

Lea-Cox, J.D. and D.S. Ross. 2001. A review of the federal Clean Water Act and the Maryland Water Quality Improvement Act-The rationale for developing a water and nutrient management planning process for container nursery and greenhouse operations. J. Environ. Hort. 19:226229.

Lieth, J.H. and L.R. Oki. 2008. Irrigation in soilless production, p. 117-156. In: M. Raviv and J.H. Lieth (eds.). Soilless culture: Theory and practice. Elsevier, Amsterdam, The Netherlands.

Liu, J., W.R. Leatherwood, and N.S. Mattson. 2012. Irrigation method and 
fertilizer concentration differentially alter growth of vegetable transplants. HortTechnology 21:56-63.

Lumis, G., P. Purvis, and L. Taurins. 2000. Flood irrigation of containergrown Euonymus and Thuja as affected by fertilizer rate and substrate. J. Environ. Hort. 18:13-17.

Martinetti, L., A. Ferrante, and E. Quattrini. 2008. Effect of drip or subirrigation on growth and yield of Solanum melongena L. in closed systems with salty water. Res. J. Biol. Sci. 3:467-474.

Martinez, H. and J. Silva Filho. 2006. Introduction to hydroponics plant cultivation. 3rd ed. Univ. Viçosa, Viçosa, Brazil.

Martínez, F., S. Castillo, E. Carmona, and M. Avilés. 2010. Dissemination of Phytophthora cactorum, cause of crown rot in strawberry, in open and closed soilless growing systems and the potential for control using slow sand filtration. Sci. Hort. 125:756-760.

Majsztrik, J.C., A.G. Ristvey, and J.D. Lea-Cox. 2011. Water and nutrient management in the production of containergrown ornamentals. Hort. Rev. 38: 253-296.

Meador, D.P., P.R. Fisher, P.F. Harmon, N.A. Peres, M. Teplitski, and C.L. Guy. 2012. Survey of physical, chemical, and microbial water quality in greenhouse and nursery irrigation water. Hort Technology 22:778-786.

Melo, J.C.F., E.S. Gervásio, and R.A. Armindo. 2013. Automation system for the subirrigation management in greenhouse. Irriga Brazilian J. Irr. Drainage 18:337-350.

Miller, C.T., N.S. Mattson, and W.B. Miller. 2011. Fertilizer composition, concentration, and irrigation method affect growth and development of Oxalis regnellii and O. triangularis. HortScience 46:1110 1115 .

Million, J.B., J.E. Barrett, T.A. Nell, and D.G. Clark. 1999. Inhibiting growth of flowering crops with ancymidol and paclobutrazol in subirrigation water. HortScience 34:1103-1105.

Million, J.B., J.E. Barrett, T.A. Nell, and D.G. Clark. 2002. One-time vs. continuous application of paclobutrazol in subirrigation water for the production of bedding plants. HortScience 37:345-347.

Million, J., T. Yeager, and C. Larsen. 2007. Water use and fertilizer response of azalea using several no-leach irrigation methods. HortTechnology 17:21-25.

Montesano, F.F., A. Parente, and P. Santamaria. 2010. Closed cycle subirriga- tion with low concentration nutrient solution can be used for soilless tomato production in saline conditions. Sci. Hort. 124:338-344.

Morvant, J.K., J.M. Dole, and E. Allen. 1997. Irrigation systems alter distribution of roots, soluble salts, nitrogen, and $\mathrm{pH}$ in the root medium. HortTechnology 7: $156-160$.

Nelson, P.V. 2003. Greenhouse operation and management. 6th ed. Prentice Hall, Upper Saddle River, NJ

Nemali, K.S. and M.W. van Iersel. 2004a. Light intensity and fertilizer concentration: I. Estimating optimal fertilizer concentrations from water-use efficiency of wax begonia. HortScience 39:12871292.

Nemali, K.S. and M.W. van Iersel. 2004b. Light intensity and fertilizer concentration: II. Optimal fertilizer solution concentration for species differing in light requirement and growth rate. HortScience 39:1293-1297.

Nemali, K.S. and M.W. van Iersel. 2006. An automated system for controlling drought stress and irrigation in potted plants. Sci. Hort. 110:292-297.

Oh, M.M., Y.Y. Cho, K.S. Kim, and J.E. Son. 2007. Comparisons of water content of growing media and growth of potted kalanchoe among nutrient-flow wick culture and other irrigation systems. HortTechnology 17:62-66.

Payne, R.N. and S.M. Adam. 1980. Influence of rate and placement of slowrelease fertilizer on pot plants of african violet grown with capillary mat watering. HortScience 15:607-609.

Pennisi, S.V., M.W. van Iersel, and S.E. Burnett. 2005. Photosynthetic irradiance and nutrition effects on growth of english ivy in subirrigation systems. HortScience 40:1740-1745

Pinto, J.R., R.A. Chandler, and R.K. Dumroese. 2008. Growth, nitrogen use efficiency, and leachate comparison of subirrigated and overhead irrigated pale purple coneflower seedlings. HortScience 43:897-901.

Poole, R.T. and C.A. Conover. 1992 Fertilizer levels and medium affect foliage plant growth in an ebb and flow irrigation system. J. Environ. Hort. 10: 81-86.

Ribeiro, M.D., R.S. Ferrarezi, and R. Testezlaf. 2014. Assessment of subirrigation performance in eucalyptus seedling production. Hort Technology 24:231-237.

Roeber, R.U. 2010. Environmentally sound plant production by means of soilless cultivation. Comunicata Scientiae 1:1-8.
Rouphael, Y. and G. Colla. 2005. Growth, yield, fruit quality and nutrient uptake of hydroponically cultivated zucchini squash as affected by irrigation systems and growing seasons. Sci. Hort. 105:177-195.

Rouphael, Y. and G. Colla. 2009. The influence of drip irrigation or subirrigation on zucchini squash grown in closed-loop substrate culture with high and low nutrient solution concentrations. HortScience 44:306-311

Rouphael, Y., M. Cardarelli, E. Rea, A. Battistelli, and G. Colla. 2006. Comparison of the subirrigation and drip-irrigation systems for greenhouse zucchini squash production using saline and non-saline nutrient solutions. Agr. Water Mgt. 82:99117.

Rouphael, Y., M. Cardarelli, E. Rea, and G. Colla. 2008. The influence of irrigation system and nutrient solution concentration on potted geranium production under various conditions of radiation and temperature. Sci. Hort. 118:328-337.

Runia, W.T. 1995. A review of possibilities for disinfection of recirculation water from soilless cultures. Acta Hort. 382:221-229.

Salvador, C.A. 2010. Irrigation system by capillary action in the citrus rootstocks production in seedings stage. Univ. Campinas, Campinas, Brazil, MS Thesis.

Santamaria, P., G. Campanile, A. Parente, and A. Elia. 2003. Subirrigation vs dripirrigation: Effects on yield and quality of soilless grown cherry tomato. J. Hort. Sci. Biotechnol. 78:290-296.

Sanogo, S. and G.W. Moorman. 1993. Transmission and control of Pythium aphanidermatum in an ebb-and-flow subirrigation system. Plant Dis. 77:287290.

Schmal, J.L., P.O. Wollery, J.P. Sloan, and C.D. Fleege. 2007. A low-tech, inexpensive subirrigation system for production of broadleaved species in large containers. Native Plants J. 8:267-269.

Schmal, J.L., R.K. Dumroese, A.S. Davis, J.R. Pinto, and D.F. Jacobs. 2011. Subirrigation for production of native plants in nurseries-Concepts, current knowledge, and implementation. Native Plants J. 12:81-93.

Son, J., M.M. Oh, Y. Lu, K. Kim, and G. Giacomelli. 2006. Nutrient-flow wick culture system for potted plant production: System characteristics and plant growth. Sci. Hort. 107:392-398.

Stanghellini, M.E., C.J. Nielsen, D.H. Kim, S.L. Rasmussen, and P.A. Rorbaugh. 2000 . Influence of sub-versus top-irrigation and surfactants in a recirculating system on disease incidence caused by Phytophthora 
spp. in potted pepper plants. Plant Dis. 84:1147-1150.

Stanwood, P.C., J.C. Phillips, and D.O. Chilcote. 1974. Fully automatic subirrigation system for glasshouse and growth chamber use. Crop Sci. 14:773-774.

Stewart-Wade, S.M. 2011. Plant pathogens in recycled irrigation water in commercial plant nurseries and greenhouses: Their detection and management. Irrig. Sci. 29:267-297.

Teixeira, P.T.L., G. Schäfer, P.V.D. Souza, and A. Todeschini. 2010. Vegetative growth and dry matter accumulation with fertilization of citrus rootstocks grown in container. Ciência Rural 40: 2603-2607.

Thebaldi, M.S. 2011. Irrigation of seedlings of native forest species grown in tubes. Univ. Lavras, Lavras, Brazil, MS Thesis.

Thinggaard, K. and A.L. Middelboe. 1989. Phytophthora and Pythium in pot plant cultures grown on ebb and flow bench with recirculating nutrient solution. J. Phytopathol. 125:343-352.

Thomas, M.D., R.H. Hendricks, J.O. Ivie, and G.R. Hill. 1943. An installation of large sand-culture beds surmounted by individual air-conditioned greenhouses. Plant Physiol. 18:334-344.

Todd, N.M. and D.W. Reed. 1998. Characterizing salinity limits of new guinea impatiens in recirculating subirrigation. J. Amer. Soc. Hort. Sci. 123:156-160.

U.S. Department of Agriculture. 2009. Census of horticultural specialties. U.S. Dept. Agr., Natl. Agr. Stat. Serv., Washington, DC.

Uva, W.F.L., T.C. Weiler, and R.A. Milligan. 1998. A survey on the planning and adoption of zero runoff subirrigation systems in greenhouse operations. HortScience 36:167-173.
Uva, W.F.L., T.C. Weiler, and R.A. Milligan. 2001. Economic analysis of adopting zero runoff subirrigation in greenhouse operations in the northeast and north central United States. HortScience 36:167-173.

Uva, W.F.L., T.C. Weiler, R.A. Milligan, L.D. Albright, and D.A. Haith. 2000. Risk analysis of adopting zero runoff subirrigation systems in greenhouse operations: A Monte Carlo simulation approach. Agr. Resource Econ. Rev. 29:229-239.

van der Gaag, D.J., A. Kerssies, and C. Lanser. 2001. Spread of phytophthora root and crown rot in saintpaulia, gerbera and spathiphyllum pot plants in ebb-and-flowsystems. Eur. J. Plant Pathol. 107:535542.

van Iersel, M.W. 1999. Fertilizer concentration affects growth and nutrient composition of subirrigated pansies. HortScience 34:660-663.

van Iersel, M.W. 2000. Postproduction leaching affects the growing medium and respiration of subirrigated poinsettias. HortScience 35:250-253.

van Iersel, M.W., M.R. Chappell, and J. LeaCox. 2013. Sensors for improved efficiency of irrigation in greenhouse and nursery production. HortTechnology 23:735-746.

van Iersel, M.W. and K.S. Nemali. 2004. Drought stress can produce small but not compact marigolds. HortScience 39:12981301 .

van Iersel, M.W., R.D. Oetting, and D.B. Hall. 2000. Imidacloprid applications by subirrigation for control of silverleaf whitefly (Homoptera: Aleyrodidae) on poinsettia. J. Econ. Entomol. 93:813-819.

van Iersel, M.W. and J.G. Kang. 2002. Nutrient solution concentration affects whole-plant $\mathrm{CO}_{2}$ exchange and growth of subirrigated pansy. J. Amer. Soc. Hort. Sci. 127:423-429. van Iersel, M.W., R.D. Oetting, D.B. Hall, and J.G. Kang. 2001. Application technique and irrigation method affect imidacloprid control of silverleaf whiteflies (Homoptera: Aleyrodidae) on poinsettias. J. Econ. Entomol. 94:666-672.

Watanabe, H., K. Kageyama, Y. Taguchi, H. Horinouchi, and M. Hyakumachi. 2008. Bait method to detect pythium species that grow at high temperatures in hydroponic solutions. J. Gen. Plant Pathol. 74:417-424.

Withrow, R.B. and J.P. Biebel. 1936. A subirrigation method of supplying nutrient solutions to plants growing under commercial and experimental conditions. J. Agr. Res. 53:693-701.

Withrow, R.B. and J.P. Biebel. 1937. Nutrient solution methods of greenhouse crop production. Purdue Univ. Agr. Expt. Sta. Circ. 232.

Yelanich, M.V. and J.A. Biernbaum. 1988. Fertilization and irrigation of bedding plants with subirrigation and recirculated water. HortScience 23:782.

Zhang, H. and W.R. Graves. 1995. Subirrigation to root stem cuttings: Comparison to intermittent mist and influence of fertilization. HortTechnology 5:265-268.

Zheng, Y., D.F. Cayanan, and M. Dixon. 2010. Optimum feeding nutrient solution concentration for greenhouse potted miniature rose production in a recirculating subirrigation system. HortScience 45:1378-1383.

Zheng, Y., T.H. Graham, S. Richar d, and M. Dixon. 2004. Potted gerbera production in a subirrigation system using low-concentration nutrient solutions. HortScience 39:1283-1286. 